\title{
Micronutrients $(\mathrm{Zn} / \mathrm{Mn})$, seaweed extracts, and plant growth-promoting bacteria as cold-stress protectants in maize
}

\author{
Klara Bradáčová ${ }^{1}$ Nino F. Weber ${ }^{1}$, Narges Morad-Talab , Mahmood Asim', Muhammad Imran²,
} Markus Weinmann ${ }^{1}$ and Guenter Neumann ${ }^{1 *}$

\begin{abstract}
Background: Low soil temperature in spring is a major constraint for cultivation of tropical crops in temperate climates, associated with impaired seedling development, inhibition of root growth and root activity. In this study, potential cold-stress protectants, such as supplemented micronutrients ( $Z n, M n)$, seaweed extracts, and rhizobacteria with plant growth-promoting potential (PGPRs) were tested in order to improve the tolerance of maize to low root zone temperatures (RZT) during early growth.

Methods: Maize (v. Colisee) was cultivated in a root cooling system for adjustment of the RZT. In three independent experiments, after germination at $20^{\circ} \mathrm{C}$, the cold-stress phase $\left(12-14^{\circ} \mathrm{C}\right)$ started at 14 days after sowing to simulate a cold period in spring. Micronutrients, seaweed extracts, and PGPRs were supplied by fertigation (experiment 1), fertigation and seed dressing (experiment 2), and nutrient seed priming (experiment 3). At the end of the experiments, scoring of oxidative leaf damage, biomass production, chlorophyll status (SPAD), root length density, superoxide dismutase activities in leaf and root tissues, and the shoot mineral-nutritional status were determined.

Results: Positive effects on plant growth and particularly on root development at low RZT were detected exclusively for seaweed extracts with high Zn/Mn contents and similar growth promotions were induced by $\mathrm{Zn}$ and $\mathrm{Mn}$ application in comparable amounts. This finding suggests that the selected seaweed extracts were mainly acting via improved Zn and Mn supply to the plants. It was essential that the cold-stress protectants were present during seed imbibition. The beneficial effect of $Z n / M n$ treatments and sea weed extracts was associated with increased superoxide dismutase activity in the root and leaf tissue, with key functions in antioxidative stress defense, depending on Zn, $\mathrm{Mn}, \mathrm{Cu}$, and Fe as enzymatic co-factors. Accordingly, leaf damage, shoot and root growth inhibition in cold-stressed plants was associated with a low Zn-nutritional status, mitigated by application of the cold-stress protectants.
\end{abstract}

Conclusions: Since micronutrients are effective already at low concentrations, starter applications of Zn/Mn or the respective seaweed extracts may offer an economic option for cold-stress prophylaxis in crops.

Keywords: Maize, Seaweed extract, Micronutrients, Cold-stress tolerance, Oxidative stress, Antioxidative stress defense, Superoxide dismutase, Plant growth-promoting rhizobacteria

\footnotetext{
*Correspondence: guenter.neumann@uni-hohenheim.de

1 Institute of Crop Science (340h), University of Hohenheim,

70599 Stuttgart, Germany

Full list of author information is available at the end of the article
} 


\section{Background}

Cultivation of tropical and subtropical crops, such as maize, soybean, or sorghum in temperate climates continuously increases as a consequence of global warming. However, for plant species like maize with optimum temperatures of $25-30{ }^{\circ} \mathrm{C}$ for germination and plant growth $[1,2]$, even moderately low soil temperatures $<15{ }^{\circ} \mathrm{C}$ are already detrimental to root development, fine root branching, and root elongation [3, 4]. Apart from root growth, also root activity in terms of nutrient uptake and nutrient translocation, adaptive root exudation for nutrient mobilization [5], and hormonal balances are impaired by low root zone temperatures (RZT), [6, 7]. Particularly in maize, plant growth is not only affected by limitations of the root system, since also the shoot meristem is located close to the soil surface and remains belowground even until the V6 stage [8]. Oxidative stress plays a significant role for the induction of chilling injury in low temperature-sensitive plants $[9,10]$, indicated visually by formation of oxidative leaf-damage symptoms, such as chloroses, anthocyanin formation, and leaf decolouration, later resulting in formation of necrotic areas (see Fig. 3). As an additional stress factor, also soil nutrient availability decreases with declining soil temperatures, as a consequence of lower solubility of mineral nutrients in cold soils, while the viscosity of water increases and reduces the speed of transport processes of mineral nutrients from soil to the root surface $[11,12]$. Therefore, plant availability of sparingly soluble nutrients, such as $\mathrm{P}$, $\mathrm{NH}_{4}^{+}, \mathrm{K}, \mathrm{Fe}, \mathrm{Zn}, \mathrm{Mn}$, and $\mathrm{Cu}$ is particularly affected by low soil temperatures. Under favorable conditions, short cold periods can be tolerated and later compensated during plant development until final harvest. However, longer stress periods can easily induce irreversible damage already in the seedling stage [13].

Various strategies have been proposed as practical measures to counteract low temperature stress in crops:

1. Fertilizer placement close to the seedling roots is currently the most widely employed approach to support root uptake of limiting nutrients, such as $\mathrm{P}$ and $\mathrm{N}$, in some cases also including $\mathrm{Zn}, \mathrm{Mn}$, and Fe as micronutrients. Imran et al. [14] demonstrated that even soaking seeds in (Zn, Mn, Fe) micronutrient solutions (seed nutrient priming) could partially restore root growth and nutrient uptake of maize seedlings exposed to low RZT of $12{ }^{\circ} \mathrm{C}$, associated with a final yield increase of $10 \%$ in two independent field experiments.

2. Application of seaweed extracts (mainly obtained from Asophyllum nodosum) with antioxidative and membrane-protective properties (reviewed by Sangha et al. [15]).
3. Improving root growth and plant nutrient acquisition by inoculation with plant growth-promoting microorganisms (PGPRs), particularly using cold-tolerant bacterial strains (psychrotolerant bacteria) with the ability to maintain phytohormone production, nutrient mobilization (siderophores), or degradation of excessive ethylene levels even at low soil temperatures (reviewed by Subramanian et al. [16]).

This study was designed as a comparative evaluation of approaches to mitigate cold-stress during early growth of maize under controlled root zone temperatures. The selected mitigation strategies comprised (1) fertigation and seed treatments with micronutrients ( $\mathrm{Zn}, \mathrm{Mn}$ ) important for oxidative stress defense [14, 17]; (2) fertigation with seaweed extracts of different origins; and (3) inoculation with plant growth-promoting and psychrotolerant bacteria.

\section{Methods}

\section{Plant cultivation}

Zea mays L cv. Colisee was used as test plant. Soil material (silty-loam, $\mathrm{pH}$ 6.9) was derived from the Ap horizon of a maize cultivation field site at the Hohenheim University experimental station Ihinger Hof, Renningen, Germany. After sieving with $2 \mathrm{~mm}$ mesh size, fertilization was performed with $\mathrm{Ca}\left(\mathrm{NO}_{3}\right)_{2}, 100 \mathrm{mg} \mathrm{N} \mathrm{kg}^{-1} \mathrm{DM}$; $\mathrm{Ca}\left(\mathrm{H}_{2} \mathrm{PO}_{4}\right)_{2}, 80 \mathrm{mg} \mathrm{P} \mathrm{kg}{ }^{-1} \mathrm{DM} ; \mathrm{K}_{2} \mathrm{SO}_{4}, 150 \mathrm{mg} \mathrm{K} \mathrm{kg}^{-1}$ $\mathrm{DM}$ and $\mathrm{MgSO}_{4}, 50 \mathrm{mg} \mathrm{Mg} \mathrm{kg}{ }^{-1} \mathrm{DM}$. For improvement of the soil structure, the fertilized soil was mixed with quartz sand (ratio 2:1). Plastic pots with a volume of $1275 \mathrm{~cm}^{3}$ were filled with the soil substrate and inserted into a cooling system, designed to control the root zone temperature of plants. An immersion water bath circulator (Thermomix 1480/Frigomix 1497, Braun, Melsungen, Germany) was connected to the cooling system containing a closed pipe system, installed in moist peat culture substrate to circulate the refrigerating fluid through the moist peat layer. The plants were regularly watered to $70 \%$ of substrate water holding capacity (WHC) with distilled water (Additional file 1: Figure S1).

Hydroponic culture with a the nutrient solution containing $2 \mathrm{mM} \mathrm{Ca}\left(\mathrm{NO}_{3}\right)_{2}, 0.7 \mathrm{mM} \mathrm{K}_{2} \mathrm{SO}_{4}, 0.1 \mathrm{mM} \mathrm{KCl}$, $0.5 \mathrm{mM} \mathrm{MgSO}_{4}, 0.1 \mathrm{mM} \mathrm{KH} \mathrm{PO}_{4}, 10 \mu \mathrm{M} \mathrm{H}_{3} \mathrm{BO}_{3}, 0.5 \mu \mathrm{M}$ $\mathrm{MnSO}_{4}, 0.2 \mu \mathrm{M} \mathrm{CuSO}_{4}, 0.01 \mu \mathrm{M}\left(\mathrm{NH}_{4}\right)_{6} \mathrm{Mo}_{7} \mathrm{O}_{24}, 0.5 \mu \mathrm{M}$ $\mathrm{ZnSO}_{4}$, and $20 \mu \mathrm{M}$ Fe-EDTA. pH 6.0-6.5 was performed as described by Imran et al. [14].

\section{Application of plant growth-promoting rhizobacteria, micronutrients, and seaweed extracts}

Commercial products and micronutrients $\left(\mathrm{ZnSO}_{4}\right.$, $\mathrm{MnSO}_{4}$ ) were applied (1) as fertigation treatments with a pipette close to the plant, directly on top of the soil 
substrate in three weekly intervals, starting with the sowing date (experiment 1); (2) single starter fertigation vs three weekly applications for seaweed extracts, and $\mathrm{Zn} /$ Mn seed dressing with Lebosol ${ }^{\circledR} \mathrm{Mn}^{500} \mathrm{SC}$ and Lebosol ${ }^{\circledR}$ $\mathrm{Zn}^{700} \mathrm{SC}$ (Lebosol ${ }^{\circledR}$ Dünger GmbH, Elmstein, Germany), according to the manufacturer instructions (experiment 2); (3) micronutrient seed priming (experiment 3) according to Imran et al. [14].

\section{Plant growth-promoting rhizobacteria}

- Proradix ${ }^{\circledR}$ WP (Sourcon Padena, Tübingen, Germany); active ingredient: Pseudomonas sp. DSMZ 13134. Dosage per application: $1 * 10^{9} \mathrm{CFU} \mathrm{kg}{ }^{-1}$ dry soil substrate.

- RhizoVital ${ }^{\circledR}$ FZB42 (ABiTEP, Berlin, Germany); active ingredient: Bacillus amyloliquefaciens subsp. plantarum. Dosage per application: $1^{*} 10^{9} \mathrm{CFU} \mathrm{kg}{ }^{-1}$ dry soil substrate.

- R41 (ABiTEP, Berlin, Germany); active ingredient: cold-resistant Bacillus simplex strain R41. Dosage per

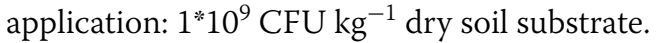

\section{Sea weed extracts}

- Super Fifty ${ }^{\circledR}$ (BioAtlantis, Tralee, Ireland); active ingredient: Ascophyllum nodosum extract. Dosage per application: $17 \mathrm{mg} \mathrm{kg}^{-1}$ dry soil substrate.

- Algavyt Zn/Mn (Agriges, San Salvatore Telesino, Italy); active ingredient: extracts from Ascophyllum nodosum, Fucus spp., Laminaria spp., $+\mathrm{Zn} / \mathrm{Mn}$. Dosage per application: $16 \mathrm{mg} \mathrm{kg}^{-1}$ dry soil substrate.

- Algafect (Agriges, San Salvatore Telesino, Italy); active ingredient: extracts from Ascophyllum nodosum, Fucus spp., Laminaria spp. Dosage per application: $16 \mathrm{mg} \mathrm{kg}^{-1}$ dry soil substrate.

\section{Micronutrients}

- $\mathrm{ZnSO}_{4}$ fertigation. Dosage per application: $0.5 \mathrm{mg} \mathrm{kg}^{-1}$ dry soil substrate.

- $\mathrm{MnSO}_{4}$ fertigation. Dosage per application: $0.5 \mathrm{mg} \mathrm{kg}^{-1}$ dry soil substrate.

- Zn seed dressing. Lebosol ${ }^{\circledR} \mathrm{Zn}^{700}$ SC: $2 \mathrm{~mL} 4000$ seeds $^{-1}$

- Mn seed dressing. Lebosol ${ }^{\circledR} \mathrm{Mn}^{500}$ SC: $4 \mathrm{~mL} 4000$ seeds $^{-1}$

- $\mathrm{Zn} / \mathrm{Mn}$ seed priming. $4 \mathrm{mM} \mathrm{Zn}+2.5 \mathrm{mM} \mathrm{Mn}$ solution as $\mathrm{ZnSO}_{4} \cdot \mathrm{H}_{2} \mathrm{O}$ and as $\mathrm{MnSO}_{4} \cdot 7 \mathrm{H}_{2} \mathrm{O}$. Sixty seeds were soaked in $200 \mathrm{~mL}$ of priming solutions (distilled water as control) in the dark for $24 \mathrm{~h}$. Thereafter, seeds were taken out, rinsed with running distilled water for $1 \mathrm{~min}$ to remove excess priming solution. Subsequently, seeds were air dried at room temperature for a minimum time period of $1 \mathrm{~h} \mathrm{[14].}$

\section{Plant analysis}

Visual scoring of leaf chloroses and necroses was performed for experiment 1 and replaced by reflectometric leaf chlorophyll measurements (SPAD) for experiment 2 . Plant height, root and shoot dry matter after $60{ }^{\circ} \mathrm{C}$ ovendrying, and root length measurements were performed for all experiments (WinRHIZO root analysis software, Regent Instruments Inc., Quebec, Canada).

\section{Analysis of mineral nutrients}

One hundred milligrams of dried shoot material was ashed for $5 \mathrm{~h}$ in a muffle furnace at $500^{\circ} \mathrm{C}$. After cooling, the samples were extracted twice with $1 \mathrm{~mL}$ of $3.4 \mathrm{M} \mathrm{HNO}_{3}$ and evaporated until dryness to precipitate $\mathrm{SiO}_{2}$. The ash was dissolved in $1 \mathrm{~mL}$ of $4 \mathrm{M} \mathrm{HCl}$, subsequently diluted ten times with hot deionized water, and boiled for $2 \mathrm{~min}$ to convert meta- and pyrophosphates to orthophosphate. After addition of $0.1 \mathrm{~mL} \mathrm{Cs} / \mathrm{La}$ buffer to $4.9 \mathrm{~mL}$ ash solution, $\mathrm{Fe}$, $\mathrm{Mn}$, and $\mathrm{Zn}$ concentrations were measured using atomic absorption spectrometry (ATI Unicam Solaar 939, Thermo Electron, Waltham, USA). Spectrophotometrical determination of orthophosphate was conducted after addition of molybdate-vanadate color reagent (Hitachi U-3300 spectrophotometer, Hitachi LtD. Corporation Japan) according to the method of Gericke and Kurmies [18]. Determination of $\mathrm{Mg}$ was conducted by atomic absorption spectrometry, while $\mathrm{K}$ and $\mathrm{Ca}$ were measured by flame emission photometry (ELEX 6361, Eppendorf, Hamburg, Germany).

\section{Superoxide dismutase assay}

The superoxide dismutase (SOD) assay was optimized for root and shoot tissues of maize with reference to the method described by Beauchamp and Friedovich [19] and modifications suggested by Giannopolitis and Ries [20] and Hajiboland and Hasani [21]. One hundred milligrams of fresh plant material, frozen in liquid nitrogen and stored at $-80{ }^{\circ} \mathrm{C}$, were ground with a pre-cooled mortar and pestle, and homogenized in $1.5 \mathrm{~mL}$ extraction buffer containing $25 \mathrm{mM}$ HEPES $\mathrm{pH} 7.8$ and $0.1 \mathrm{mM}$ EDTA. After centrifugation at $10000 \times g\left(4{ }^{\circ} \mathrm{C}\right.$ for $\left.10 \mathrm{~min}\right)$, aliquots of the supernatant were transferred into $2 \mathrm{~mL}$ reaction tubes and kept on ice. For preparation of the reaction mixture, $1 \mathrm{~mL}$ cuvettes, covered with aluminum foil for light protection, were filled with $300 \mu \mathrm{L} 62.5 \mathrm{mM}$ HEPES, $75 \mu \mathrm{L} 1.0 \mathrm{mM}$ EDTA, $75 \mu \mathrm{L} 120 \mathrm{mM} \mathrm{Na}_{2} \mathrm{CO}_{3}, 75 \mu \mathrm{L} 120 \mathrm{mM}$ L-methionine, $150 \mu \mathrm{L} 750 \mu \mathrm{M}$ nitro-blue tetrazolium (NBT), and $100 \mu \mathrm{L}$ of plant extract. Finally, $225 \mu \mathrm{L} 10 \mu \mathrm{M}$ riboflavin were added. The light reaction was started by removing the aluminum foil, exposing the samples to light $(8000$ Lux) for $25 \mathrm{~min}$. During the light phase, NBT is reduced to a dark blue formazan, measured spectrophotometrically (U-3300, Hitachi, Tokyo, Japan) at a wavelength of $650 \mathrm{~nm}$. The final SOD activity, which inhibits the NBT reduction, 
was calculated as difference between absorbance of the sample and a control without plant extract, divided by $50 \%$ absorbance of the control. The SOD activity was expressed as SOD units per $\mathrm{g}$ fresh weight (FW).

\section{Statistical analyses}

The study was carried out in a completely randomized design. Data are presented as mean $\pm \mathrm{SE}$. For statistical analysis of significant differences between treatment groups, a one-way ANOVA followed by a Tukey test $(p<0.05$ significance level) were performed using the SAS/STAT software package of SAS ${ }^{\circledR}$ 9.3.

\section{Results}

\section{Experiment 1}

Maize seedlings, germinated for 2 weeks on a silty-loam soil pH 6.9 (taken from a maize field site) at a root zone temperature (RZT) of $20-22{ }^{\circ} \mathrm{C}$, followed by a twoweek low RZT treatment with $12-14{ }^{\circ} \mathrm{C}$ and a recovery period of 10 days, exhibited significantly reduced shoot growth as compared with the unstressed control
(Fig. 1). During the cold-stress period, plants developed leaf chlorosis, subsequently turning into necrotic spots, associated with anthocyanin formation, which finally affected $30-40 \%$ of the total leaf area (Fig. 2). A significant reduction of leaf damage was observed after $\mathrm{Zn} /$ Mn fertigation (5\% affected leaf area) and in the treatments with the seaweed extract combination products Algafect and Algavyt+Zn/Mn (Ascophyllum nodosum, Fucus spp., Laminaria spp.; 0-15 \% affected leaf area) but not for the pure Ascophyllum nodosum extract Super Fifty (40\% affected leaf area, Fig. 2). Accordingly, shoot growth inhibition, induced by low RZT was reverted particularly in maize plants with $\mathrm{Zn} / \mathrm{Mn}$ and Algavyt $+\mathrm{Zn} / \mathrm{Mn}$ fertigation (Fig. 2). By contrast, the treatments with plant growth-promoting rhizobacteria had no protective effects on formation of leaf necrosis (Fig. 2) and inhibition of shoot growth (Fig. 1) under low RZT. Combinations of the PGPRs with the seaweed extract Algafect resulted in a reduction of necrotic leaf area but the effect was not bigger than the treatment with the seaweed extract alone (Fig. 2).
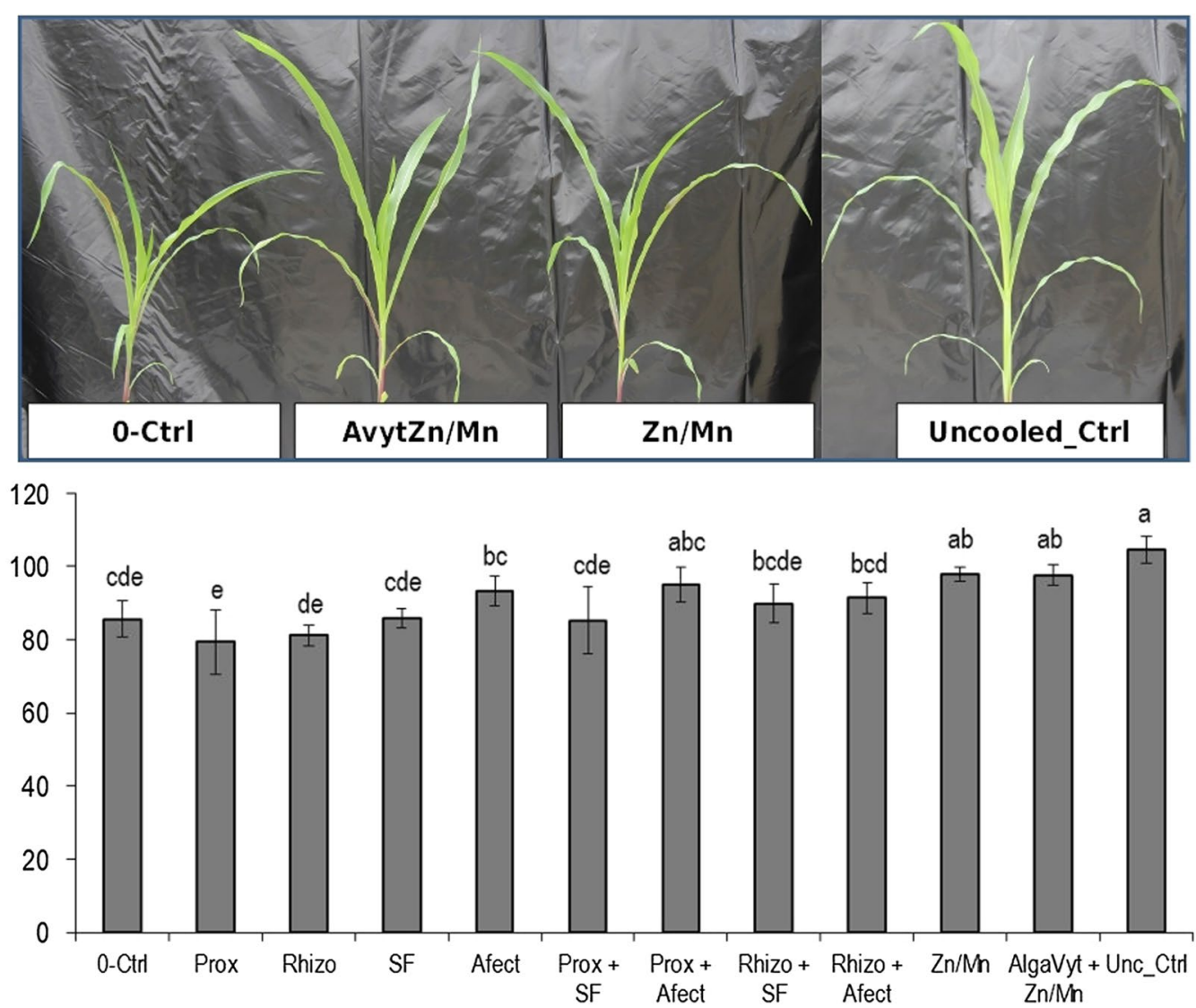

Fig. 1 Shoot length of maize plants exposed to a root zone temperature of $12-14^{\circ} \mathrm{C}$ for 2 weeks in a cooling system. 0 -Ctrl untreated control, Prox Proradix, SF Super Fifty, Rhizo Bacillus amyloliquefaciens FZB42 + Bacillus simplex R41, Afect Algafect; Unc. Ctrl uncooled control at 20-22 ${ }^{\circ} \mathrm{C}$. Data represent means and SE of five independent replicates for each treatment. Significant differences (Tukey test, $a<5 \%$ ) are marked with different letters 

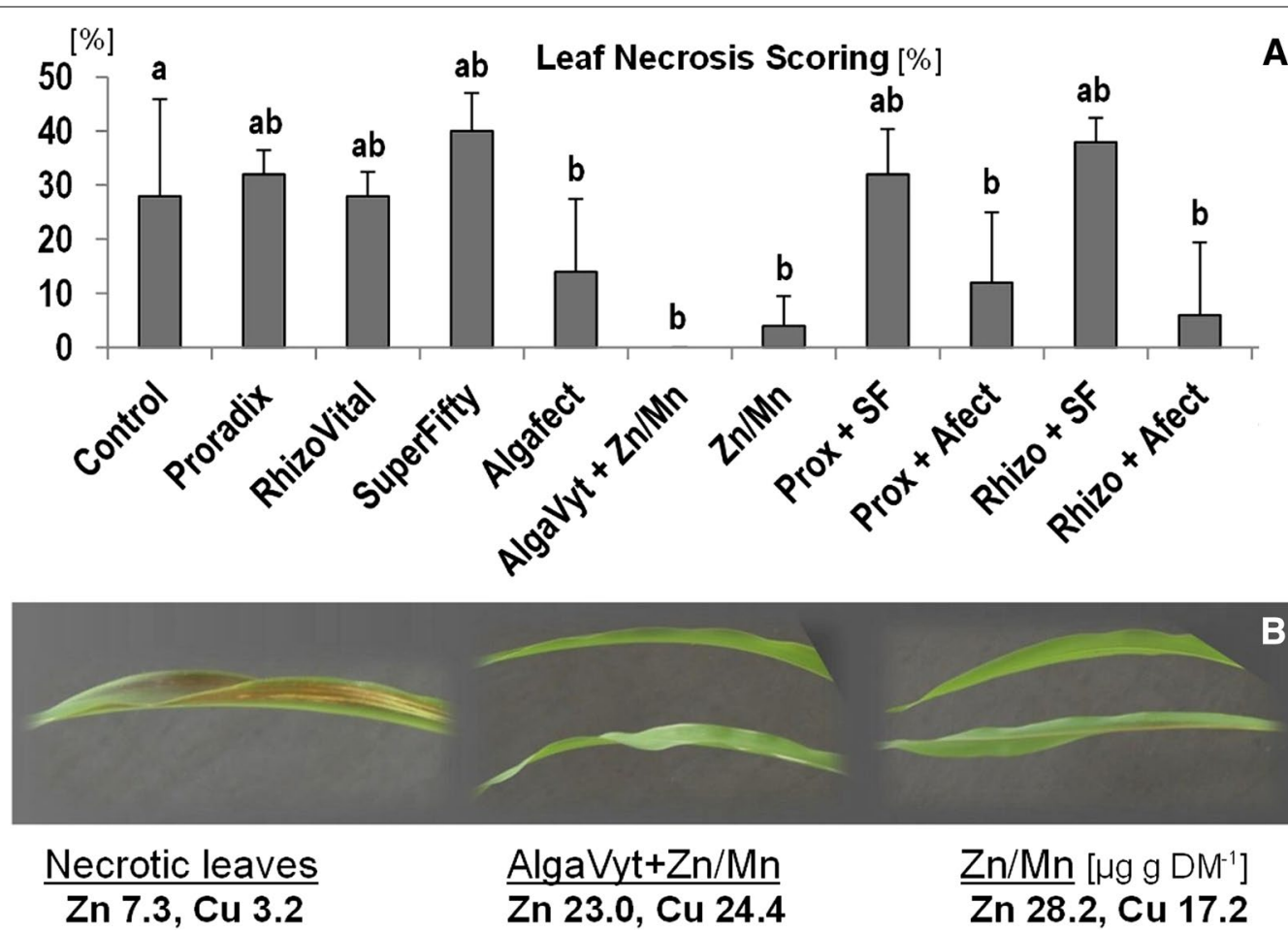

Fig. 2 Leaf damage of maize plants exposed to a root zone temperature of $12-14{ }^{\circ} \mathrm{C}$ for 2 weeks in a cooling system. Prox Proradix, SF Super Fifty, Rhizo Bacillus amyloliquefaciens FZB42 + Bacillus simplex R41, Afect Algafect. A Scoring of leaf necrosis (\% affected leaf area). B Appearance and micronutrient status (Zn, Cu $\mu \mathrm{g} \mathrm{g}{ }^{-1} \mathrm{DM}$ ] of damaged ad corresponding undamaged leaves treated with cold-stress protectants. Data represent means and SE of five independent replicates for each treatment. Significant differences (Tukey test, $a<5 \%$ ) are marked with different letters

The beneficial effects of fertigation with $\mathrm{Zn} / \mathrm{Mn}$, Algafect, and Algavyt $+\mathrm{Zn} / \mathrm{Mn}$ on cold-stress-induced leaf necrosis and inhibition of shoot growth were associated with a doubling of root length density (Fig. 3), indicating strong effects on root elongation and fine root production with outstanding importance for nutrient acquisition [22]. A closer look on the nutritional status

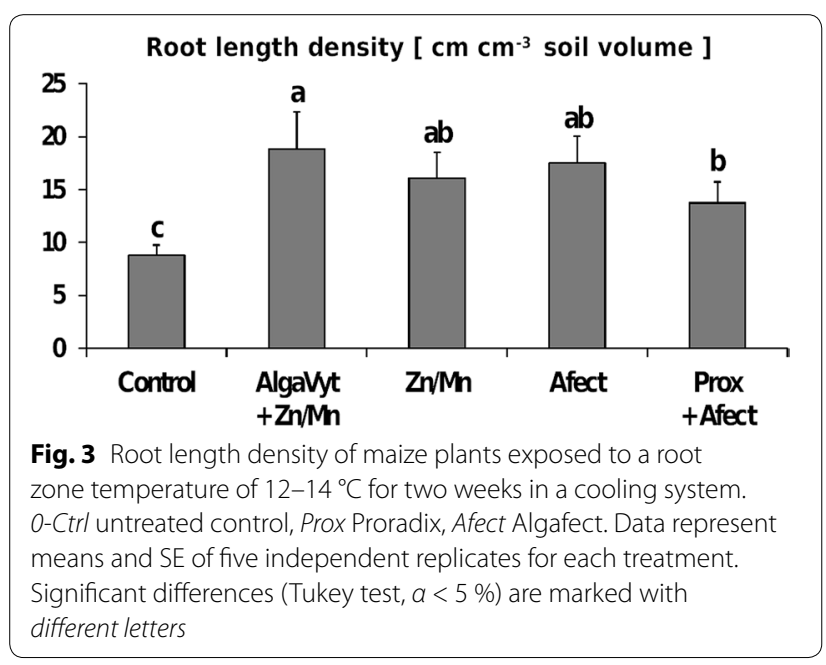

of the damaged leaf tissue in cold-stressed maize plants [23] revealed deficiencies of $\mathrm{Zn}\left(7.3 \mathrm{mg} \mathrm{kg}^{-1} \mathrm{DM}\right.$, critical threshold $\left.20 \mathrm{mg} \mathrm{kg}^{-1} \mathrm{DM}\right)$ and $\mathrm{Cu}\left(3.2 \mathrm{mg} \mathrm{kg}^{-1} \mathrm{DM}\right.$; critical threshold $5 \mathrm{mg} \mathrm{kg}^{-1} \mathrm{DM}$ ), not detectable in the corresponding leaves after fertigation with $\mathrm{Zn} / \mathrm{Mn}$ and Algavyt $+\mathrm{Zn} / \mathrm{Mn}$ (Fig. 3). The Mn concentrations were sufficient in all treatments $\left(40-50 \mathrm{mg} \mathrm{kg}^{-1} \mathrm{DM}\right)$, while the $\mathrm{P}$ status of $0.25-0.3 \%$ was low but not critical (data not shown).

Analysis of critical nutrients supplemented with the applied cold protectants revealed high levels of $\mathrm{Zn}$ and $\mathrm{Mn}$ as common micronutrients present in the seaweed extracts Algafect, Algavyt $+\mathrm{Zn} / \mathrm{Mn}\left(6-70 \mathrm{mg} \mathrm{kg}^{-1} \mathrm{DM}\right)$, and in the $\mathrm{Zn} / \mathrm{Mn}$ fertigation solution, exerting beneficial effects on cold-stressed plants but not in the pure Ascophyllum nodosum extract Super Fifty and in the microbial inoculants $\left(\leq 0.06 \mathrm{mg} \mathrm{kg}{ }^{-1} \mathrm{DM}\right)$, lacking protective activity (Table 1$)$.

\section{Experiment 2}

In face of the obvious indications for a role of micronutrients, such as $\mathrm{Zn}$ in cold-stress mitigation by the applied cold-protectants, a second experiment was conducted to investigate a putative link with SOD as 
Table 1 Mineral nutrients [ $\mathrm{mg} \mathrm{kg}^{-1} \mathrm{DM}$ ] in bacterial inoculants and seaweed extracts used in the experiments

\begin{tabular}{lllllllll}
\hline Product & $\mathbf{P}$ & $\mathbf{K}$ & $\mathbf{C a}$ & $\mathbf{M g}$ & $\mathbf{Z n}$ & $\mathbf{F e}$ & $\mathbf{C u}$ & $\mathbf{M n}$ \\
\hline Proradix $^{\circledR}$ & 9.10 & 13.20 & 9.90 & 1.09 & 0.03 & b.d. & b.d. & b.d. \\
RhizoVital $^{\circledR}$ & 1.42 & 0.56 & 1.03 & 0.44 & b.d. & b.d. & b.d. & 0.02 \\
Bacillus simplex $_{\text {Super fifty }}^{\circledR}$ & 3.63 & 0.71 & 1.78 & 0.87 & 0.03 & b.d. & b.d. & 0.06 \\
Algafect $_{\text {Algavyt+ZnMn }}$ & b.d. & 70.00 & 0.36 & 2.48 & b.d. & 0.06 & b.d. & b.d. \\
\hline
\end{tabular}

b.d. below detection limit

key enzymes in oxidative stress protection, with $\mathrm{Zn}$, $\mathrm{Mn}, \mathrm{Cu}$, and $\mathrm{Fe}$ as co-factors [17]. Moreover, in the first experiment, fertigation with cold-protectants was performed in weakly intervals during the first 3 weeks after sowing, difficult to perform under real practice conditions. Therefore, in the second experiment also the more realistic option of a single starter application of promising cold-protectants at the time of sowing was tested: Algavyt $+\mathrm{Zn} / \mathrm{Mn}$ was supplied as single fertigation treatment directly after sowing, as compared with three weekly applications. Zn/Mn was supplied once as a starter application, using a commercial seeddressing formulation (Lebosol Dünger GmbH, Elmstein, Germany).

At 6 weeks after sowing, shoot length and shoot biomass production of maize plants exposed to low RZT of $12-14^{\circ} \mathrm{C}$ was increased by approx. 20 and $30 \%$, respectively, in the treatments with cold-protectants without differences between single and triple applications of Algavyt $+\mathrm{Zn} / \mathrm{Mn}$ (Fig. 5a, b). Cold-stressinduced leaf chlorosis (SPAD values) declined in the order $\mathrm{Zn} / \mathrm{Mn}<\mathrm{Algavyt}+\mathrm{Zn} / \mathrm{Mn}$ (three applications) $=$ Algavyt $+\mathrm{Zn} / \mathrm{Mn}$ (one application) $<$ untreated control (Fig. 4C). Declining leaf chlorosis was associated with increasing $\mathrm{Zn}$ leaf concentrations (Fig. 4D) and increased activity of superoxide dismutase in the leaf and root tissue (Fig. 4D, E). Mineral nutrient analysis [23] revealed a low but not critical status for $\mathrm{P}$ (0.23-0.3\%) and $\mathrm{Mg}(0.17-0.19 \%)$, and $\mathrm{Ca}$ and $\mathrm{K}$ concentrations in the sufficiency range, without significant treatment differences (Table 2). The micronutrient status of the untreated control was deficient for $\mathrm{Zn}\left(12 \mathrm{mg} \mathrm{kg}^{-1}\right.$ $\mathrm{DM})$ and $\mathrm{Mn}$ (24 $\left.\mathrm{mg} \mathrm{kg}^{-1} \mathrm{DM}\right)$, increased after application of cold-stress protectants and reached the sufficiency range in the $\mathrm{Zn} / \mathrm{Mn}$ seed-dressing treatment. The $\mathrm{Fe}$ and $\mathrm{Cu}$ status was low but not critical without significant differences within the treatments (Table 2). For all investigated nutrients, total shoot contents increased in response to the treatments with cold-stress protectants (Table 3), demonstrating an improved nutrient acquisition in general.

\section{Experiment 3}

Generally, effects of single Algavyt $+\mathrm{Zn} / \mathrm{Mn}$ treatments were not smaller than the effects of triple applications, and were most pronounced in $\mathrm{Zn} / \mathrm{Mn}$ seed-dressing treatments (Fig. 4; Tables 2, 3), demonstrating the outstanding importance of a starter application at the time of sowing. This was further confirmed in a nutrient solution experiment with seeds, pre-soaked in $\mathrm{Zn} / \mathrm{Mn}$ nutrient solutions and water, respectively, subsequently germinated between filter paper and transferred for 5 weeks to a full-strength nutrient solution containing all essential mineral nutrients. During 4 weeks of the culture period, the nutrient solutions were cooled to $12{ }^{\circ} \mathrm{C}$. Analysis of plant growth revealed a cold-protective effect of $\mathrm{Zn} / \mathrm{Mn}$ treatments only when the micronutrients were applied as seed treatments prior to the onset of the coldstress period. By contrast, even continuous supply of all essential nutrients in unlimited amounts via the nutrient solution during the cold-stress period directly to the roots of the maize seedlings, had no protective effects, as demonstrated by the control variant without $\mathrm{Zn} / \mathrm{Mn}$ seed treatment (Fig. 5).

\section{Discussion}

This study was designed to compare the efficiency of different mitigation strategies against low root zone temperatures during early growth as a major constraint for maize cultivation in temperate climates [1-4], including supplementation of critical micronutrients ( $\mathrm{Zn}, \mathrm{Mn}$ ) [14], application of seaweed extracts [15], and inoculation with plant growth-promoting and cold- tolerant bacteria [16]. Surprisingly, despite a proven plant growth-promoting potential [24, 25] even in combination with the tested maize cultivar [26, 27], the investigated microbial inoculants, including a psychrotolerant strain of Bacillus simplex, failed to show any beneficial effects on growth of maize seedlings exposed to moderately low RZT of $12-14{ }^{\circ} \mathrm{C}$. It remains to be established whether other cold-resistant microbial inoculants, directly isolated from the maize rhizosphere, such as Acinetobacter rhizosphaerae $\mathrm{BIHB} 727$, Pseudomonas putida $\mathrm{B} 0$, or 

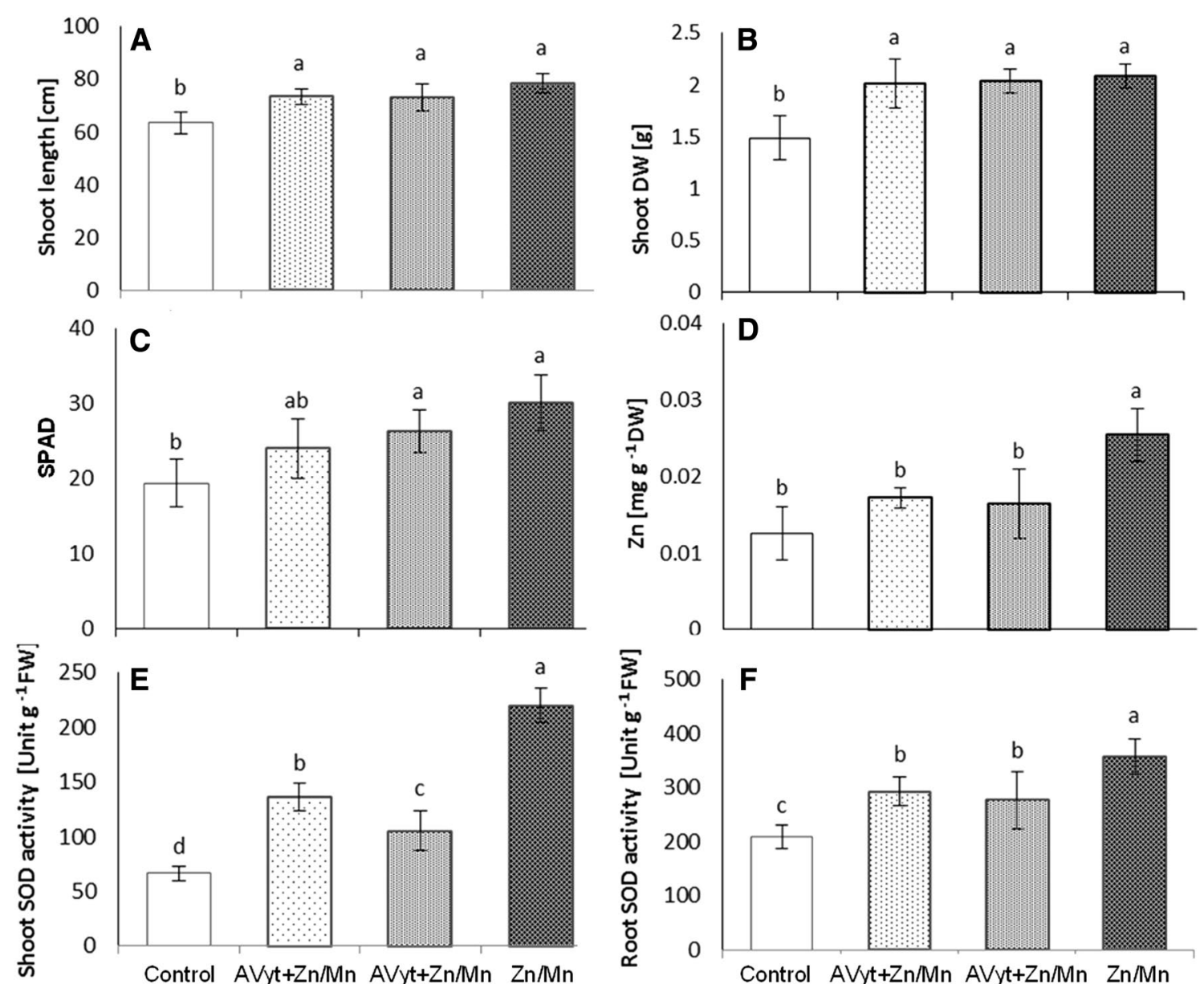

$\mathbf{F}$

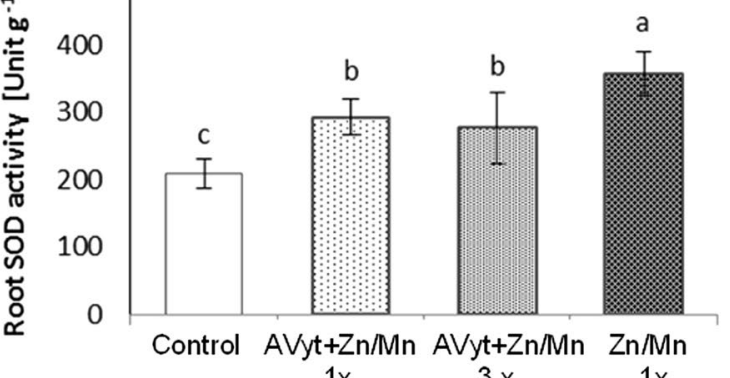

Fig. 4 A Shoot length, B Shoot biomass (DM), C SPAD values (Chlorophyll), D Zinc shoot concentration, E Superoxide dismutase (SOD) leaf activity, and $\mathbf{F}$ SOD root activity of maize plants exposed to a root zone temperature of $12-14{ }^{\circ} \mathrm{C}$ for two weeks in a cooling system. 0 -Ctrl untreated control, Prox Proradix, Afect Algafect. Data represent means and SE of five independent replicates for each treatment. Significant differences (Tukey test, $a<5 \%)$ are marked with different letters

Table 2 Shoot concentration of mineral nutrients in maize plants exposed during four weeks to a root zone temperature of 12-14 ${ }^{\circ} \mathrm{C}$ with and without $\mathrm{Zn} / \mathrm{Mn}$ seed dressing and single or triple seaweed extract applications of Algavyt+Zn/Mn

\begin{tabular}{|c|c|c|c|c|}
\hline Treatment & $\mathrm{Ca}\left(\mathrm{mg} \mathrm{g}^{-1} \mathrm{DW}\right)$ & $M g\left(\mathrm{mg} \mathrm{g}^{-1} \mathrm{DW}\right)$ & $\mathrm{K}\left(\mathrm{mg} \mathrm{g}^{-1} \mathrm{DW}\right)$ & $P\left(\mathrm{mg} \mathrm{g}^{-1} \mathrm{DW}\right)$ \\
\hline Untreated control & $4.46 \pm 0.35^{\mathrm{a}}$ & $1.65 \pm 0.17^{\mathrm{a}}$ & $3.42 \pm 0.56^{\mathrm{a}}$ & $2.53 \pm 0.32^{\mathrm{ab}}$ \\
\hline Algavyt single appl. & $4.33 \pm 0.34^{\mathrm{a}}$ & $1.70 \pm 0.23^{\mathrm{a}}$ & $3.49 \pm 0.90^{\mathrm{a}}$ & $2.30 \pm 0.24^{b}$ \\
\hline Algavyt triple appl. & $4.68 \pm 0.82^{\mathrm{a}}$ & $1.89 \pm 0.30^{\mathrm{a}}$ & $4.44 \pm 1.02^{\mathrm{a}}$ & $3.02 \pm 0.50^{\mathrm{a}}$ \\
\hline Zn/Mn seed dressing & $4.72 \pm 0.55^{\mathrm{a}}$ & $1.67 \pm 0.20^{\mathrm{a}}$ & $3.72 \pm 0.60^{\mathrm{a}}$ & $2.36 \pm 0.25^{\mathrm{ab}}$ \\
\hline Treatment & $\mathrm{Zn}\left(\mathrm{mg} \mathrm{g}^{-1} \mathrm{DW}\right)$ & $\mathrm{Mn}\left(\mathrm{mg} \mathrm{g}^{-1} \mathrm{DW}\right)$ & $\mathrm{Fe}\left(\mathrm{mg} \mathrm{g}^{-1} \mathrm{DW}\right)$ & $\mathrm{Cu}\left(\mathrm{mg} \mathrm{g}^{-1} \mathrm{DW}\right)$ \\
\hline Untreated control & $0.012 \pm 0.003^{b}$ & $0.024 \pm 0.004^{b}$ & $0.054 \pm 0.017^{a}$ & $0.005 \pm 0.001^{\mathrm{a}}$ \\
\hline Algavyt single appl. & $0.017 \pm 0.001^{b}$ & $0.028 \pm 0.004^{b}$ & $0.081 \pm 0.023^{a}$ & $0.005 \pm 0.001^{\mathrm{a}}$ \\
\hline Algavyt triple appl. & $0.016 \pm 0.004^{\mathrm{ab}}$ & $0.027 \pm 0.009^{b}$ & $0.068 \pm 0.012^{a}$ & $0.006 \pm 0.0007^{\mathrm{a}}$ \\
\hline Zn/Mn seed dressing & $0.025 \pm 0.003^{\mathrm{a}}$ & $0.048 \pm 0.013^{\mathrm{a}}$ & $0.090 \pm 0.024^{\mathrm{a}}$ & $0.006 \pm 0.001^{\mathrm{a}}$ \\
\hline
\end{tabular}

Data represent means and SE of five independent replicates for each treatment. Significant differences (Tukey test, $a<5 \%$ ) are marked with different letters (a, b) 
Table 3 Shoot accumulation of mineral nutrients in maize plants exposed during four weeks to a root zone temperature of 12-14 ${ }^{\circ} \mathrm{C}$ with and without $\mathrm{Zn} / \mathrm{Mn}$ seed dressing and single or triple seaweed extract applications of Algavyt+Zn/Mn

\begin{tabular}{|c|c|c|c|c|}
\hline Treatment & $\mathrm{Ca}\left(\mathrm{mg} \mathrm{plant}^{-1}\right)$ & $M g\left(\right.$ mg plant $\left.^{-1}\right)$ & $\mathrm{K}\left(\mathrm{mg} \mathrm{plant}^{-1}\right)$ & $\mathrm{P}\left(\mathrm{mg} \mathrm{plant}^{-1}\right)$ \\
\hline Untreated control & $6.66 \pm 1.21^{b}$ & $2.47 \pm 0.51^{b}$ & $5.06 \pm 0.84^{b}$ & $3.78 \pm 0.83^{b}$ \\
\hline Algavyt single appl. & $8.73 \pm 1.18^{\mathrm{ab}}$ & $3.40 \pm 0.45^{\mathrm{ab}}$ & $6.92 \pm 1.34^{\mathrm{ab}}$ & $4.61 \pm 0.55^{\mathrm{ab}}$ \\
\hline Algavyt triple appl. & $9.53 \pm 1.66^{\mathrm{ab}}$ & $3.84 \pm 0.0 .60^{\mathrm{a}}$ & $9.00 \pm 1.82^{\mathrm{a}}$ & $6.13 \pm 0.73^{\mathrm{a}}$ \\
\hline $\mathrm{Zn} / \mathrm{Mn}$ seed treatment & $9.81 \pm 0.89^{\mathrm{a}}$ & $3.50 \pm 0.54^{\mathrm{a}}$ & $7.45 \pm 1.90^{\mathrm{ab}}$ & $6.35 \pm 1.05^{\mathrm{a}}$ \\
\hline Treatment & $\mathrm{Zn}\left(\mathrm{mg} \mathrm{plant}^{-1}\right)$ & $\mathrm{Mn}$ (mg plant $\left.{ }^{-1}\right)$ & $\mathrm{Fe}\left(\mathrm{mg} \mathrm{plant}^{-1}\right)$ & $\mathrm{Cu}\left(\mathrm{mg} \mathrm{plant}^{-1}\right)$ \\
\hline Untreated control & $0.019 \pm 0.008^{b}$ & $0.037 \pm 0.012^{c}$ & $0.080 \pm 0.021^{b}$ & $0.007 \pm 0.002^{b}$ \\
\hline Algavyt single appl & $0.035 \pm 0.006^{\mathrm{ab}}$ & $0.056 \pm 0.008^{b}$ & $0.160 \pm 0.034^{\mathrm{a}}$ & $0.009 \pm 0.002^{\mathrm{ab}}$ \\
\hline Algavyt triple appl. & $0.034 \pm 0.010^{\mathrm{ab}}$ & $0.055 \pm 0.0 .022^{\mathrm{a}}$ & $0.140 \pm 0.045^{\mathrm{ab}}$ & $0.012 \pm 0.001^{\mathrm{a}}$ \\
\hline $\mathrm{Zn} / \mathrm{Mn}$ seed treatment & $0.053 \pm 0.008^{\mathrm{a}}$ & $0.101 \pm 0.032^{\mathrm{a}}$ & $0.190 \pm 0.058^{\mathrm{a}}$ & $0.0012 \pm 0.002^{\mathrm{a}}$ \\
\hline
\end{tabular}

Data represent means and SE of five independent replicates for each treatment. Significant differences (Tukey test, $a<5 \%)$ are marked with different letters ( $a, b, c)$

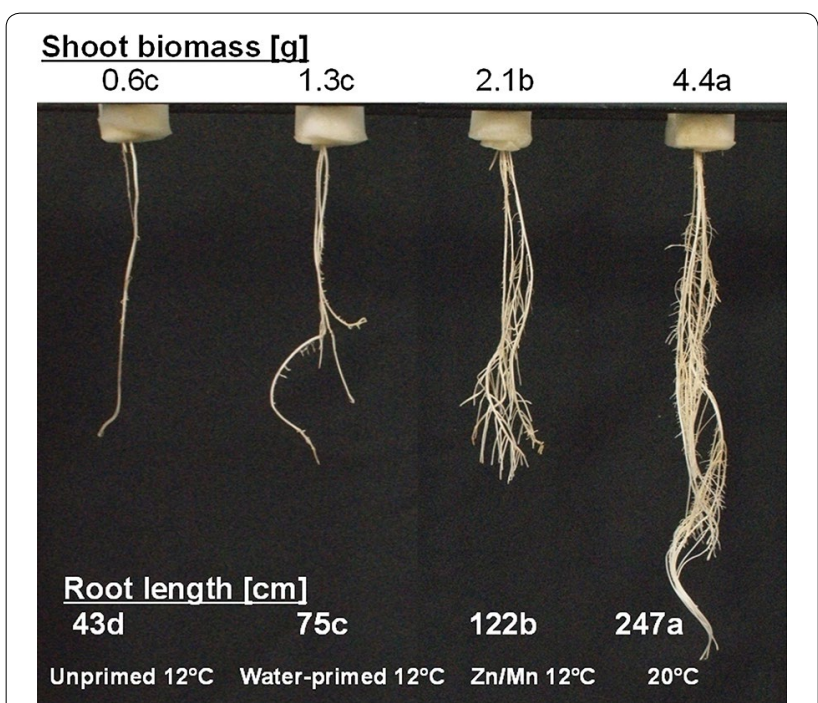

Fig. 5 Root development and shoot biomass of maize plants grown in hydroponics and exposed to a root zone temperature of $12{ }^{\circ} \mathrm{C}$ during four weeks in a cooling system. Effects of seed priming with water and $\mathrm{Zn} / \mathrm{Mn}$ [14] as compared to an untreated control grown under ambient temperature at $20^{\circ} \mathrm{C}$. Data represent means of four independent replicates for each treatment. Significant differences (Tukey test, $a<5 \%$ ) are marked with different letters

Mycoplana bullata MpB46 [16], could be more effective in this context.

In accordance with the observations of Imran et al. [14], supplementation of critical micronutrients, particularly $\mathrm{Zn}$, was effective in mitigating growth depressions (Fig. 1) and oxidative leaf damage in maize seedlings exposed to low RZT (Fig. 2). Oxidative stress may represent the physiological link between micronutrient supply and chilling tolerance, and has been characterized as an important stress factor in cold-stressed plants [28].
Reduced shoot and root growth of maize plants exposed to low temperatures has been attributed to severe oxidative damage induced by cold stress $[13,29]$. The different isoforms of $\mathrm{SO}$ as key enzyme for detoxification of free radicals, strongly depend on $\mathrm{Zn}, \mathrm{Mn}, \mathrm{Cu}$, and $\mathrm{Fe}$ as cofactors and have been implicated in chilling tolerance of higher plants [29]. Accordingly, our study revealed increased in vitro activity of SOD in leaves by supplementation of mineral $\mathrm{Zn} / \mathrm{Mn}$ fertilizers (Fig. 4).

In addition to the mitigation of oxidative leaf damage and shoot growth inhibition, as one of the most striking effects, fertigation with $\mathrm{Zn} / \mathrm{Mn}$ solutions or $\mathrm{Zn} / \mathrm{Mn}$-rich seaweed extracts (Algafect, Algavyt $+\mathrm{Zn} / \mathrm{Mn}$ ) doubled the root length density of cold-stressed maize plants (Fig. 4), similarly reported also by Imran et al. [14]. Apart from lipid peroxidation, an increased oxidative degradation of auxins as a consequence of CuZnSOD limitation has been discussed as a mechanism for reduction of plant growth in response to $\mathrm{Zn}$ deficiency [6, 30]. Accordingly, external Zn/Mn supply to cold-stressed plants inducing an increased SOD activity (Fig. 4), may exert a protective effect against oxidative auxin degradation, thereby maintaining auxin levels sufficiently high to trigger root and shoot elongation even at low RZT. Recent studies also suggest that particularly auxin transport rather than auxin synthesis is affected by cold stress [7]. Stimulation of root growth may explain the increased accumulation also of other mineral nutrients in the shoot tissue of the $\mathrm{Zn} / \mathrm{Mn}$-treated maize plants (Table 3) as a consequence of improved spatial nutrient acquisition. However, apart from auxins, cold stress affects hormonal balances via positive and negative interactions with a wide range of phytohormones and signal compounds, including cytokinins, gibberellins, jasmonic acid, ABA, salicylic acid, and there is no information on putative effects of micronutrient availability on these processes [7]. 
Surprisingly, improved $\mathrm{Zn} / \mathrm{Mn}$ supply seems to be also the mechanism behind cold-stress mitigation mediated by application of seaweed extracts, since only seaweed extracts rich in $\mathrm{Zn} / \mathrm{Mn}$ (Algafect 20.8/6.6 $\mathrm{mg} \mathrm{kg}^{-1} \mathrm{DM}$; Algavyt $\left.+\mathrm{Zn} / \mathrm{Mn} 71.9 / 59.6 \mathrm{mg} \mathrm{kg}^{-1} \mathrm{DM}\right)$ exerted protective effects against low RZT, while the highly concentrated and purified Ascophyllum nodosum extract "Super Fifty" without detectable $\mathrm{Zn} / \mathrm{Mn}$ contents was completely ineffective (Fig. 2). This result was unexpected since in the available literature, protective effects of seaweed extracts against abiotic stresses have been mainly related with the organic fraction $[15,32]$. However, in many cases these applications refer to foliar treatments [15] and to extracts obtained with lipophilic solvents supplied in agar media [31]. It is not clear whether the same compounds are active in the fertigation treatments applied in the present study, since adsorption and microbial degradation processes may occur in soils, as a source of interference not present in case of foliar applications. More detailed chemical fractionation experiments are required for further testing the hypothesis that micronutrients and particularly $\mathrm{Zn}$ are the major active ingredients of seaweed extracts used for soil applications as antioxidative cold-stress protectants.

Another interesting result was the finding that the application timing of the cold-stress protectants was obviously more important than the number of applications, and single starter applications of $\mathrm{Zn} / \mathrm{Mn}$ or $\mathrm{Zn} /$ Mn-rich seaweed extracts were equally effective than weekly applications during the first 21 DAS (Fig. 4). The nutrient solution experiment even demonstrated that $\mathrm{Zn} / \mathrm{Mn}$ treatments could only exert a protective effect against cold stress when the micronutrients were present during seed imbibition prior to the onset of the coldstress period. This effect could not be replaced by later applications of micronutrients to the germinated seedling roots, even with unlimited supply of all essential nutrients in a full nutrient solution (Fig. 5). Since the micronutrients are taken up by the seeds during imbibition [14], this may indicate that only the micronutrient fraction already present in the plant tissue can exert a protective function after onset of the cold-stress period, while root uptake from the external medium is largely inhibited under these conditions. This is in line with observations of Engels et al. [32, 33], demonstrating that $\mathrm{Zn}$ and Mn shoot accumulation in maize exposed to low RZT was particularly dependent on cold-stress effects affecting root activity, while the uptake of other nutrients was more strongly determined by the shoot demand.

The efficiency of starter treatments with micronutrients or seaweed extracts could also be a big advantage from the practical point of view, since it facilitates integration into common sowing techniques, such as seed dressings or underfoot placement of fertilizers, provided that suitable formulations are available. By contrast, repeated applications would largely increase the application costs due to a higher dosage and additional workload. Since micronutrients are effective already at low application doses, starter applications of $\mathrm{Zn} / \mathrm{Mn}$ or the respective seaweed extracts may offer a highly economic option for cold-stress prophylaxis in crops. Assuming a field planting density of six maize plants $\mathrm{m}^{-2}$ (60.000 plants ha $\left.{ }^{-1}\right)$, one single application of $\mathrm{Zn} / \mathrm{Mn}$-rich seaweed extract would translate into a dose of approx. $1 \mathrm{~kg} \mathrm{ha}^{-1}$. In case of $\mathrm{Zn} / \mathrm{Mn}$ sulfate fertigation, already $30 \mathrm{~g} \mathrm{ha}^{-1}$ would be sufficient. Recommended dosages for underfoot placement are in the range of $300 \mathrm{~g} \mathrm{ha}^{-1}$. In case of micronutrient seed priming [14], the dose would be even lower (2-3 $\left.\mathrm{g} \mathrm{ha}^{-1}\right)$ and translated into a maize grain yield increase of approx. $10 \%$ in two independent field experiments [14].

\section{Outlook and concluding remarks}

The beneficial effects of starter treatments with micronutrients (particularly $\mathrm{Zn}$ ) or seaweed extracts acting via the antioxidative stress defense system on cold-stress tolerance of the target plants are obvious but the detailed mode of action is still not fully understood. Also field performance requires further confirmation on different soils. The various successful application modes and formulations, such as seed priming, seed dressing, fertigation, supplementation in form of pure mineral nutrients or as seaweed extracts may offer high flexibility for different sowing techniques, underfoot fertilization, organic vs conventional farming etc., but still requires optimization of the application dosage. Apart from improved cold-stress tolerance, both, micronutrient fertilization and seaweed extracts have documented effects on plant growth promotion and tolerance against other biotic and abiotic stress factors [16, 17, 34]. Therefore, additional beneficial effects may be expected under stress conditions not addressed in the present study.

\section{Additional file}

Additional file 1: Figure S1. Cooling system for adjustment of low root zone temperature based on mois peat culture substrate with cooling tubes. A) Pots with germinating maize seedlings inserted into the cooling system. B) Overview at final harvest.

\section{Authors' contributions}

$K B, N F W$, and NMT equally contributed to the setup and evaluation of the soil culture experiments under controlled RZT and prepared the manuscript. MW was involved in setup of the cooling system and adaptation of the SOD determination. MA and MI were responsible for the nutrient seed priming experiment in hydroponic culture. GN designed the experiments and was 
involved in proof reading and final editing of the manuscript. All authors read and approved the final manuscript.

\section{Author details}

${ }^{1}$ Institute of Crop Science (340h), University of Hohenheim, 70599 Stuttgart, Germany. ${ }^{2}$ Institut für Pflanzenernährung und Bodenkunde, Christian-Albrechts-Universität zu Kiel, Hermann-Rodewald-Str. 2, Kiel, Germany.

\section{Acknowledgements}

This work was supported by the European's Seventh Framework Programme (FP/2007-2013) under Grant Agreement no. 312117.

\section{Competing interests}

The authors declare that they have no competing interests.

Received: 15 January 2016 Accepted: 22 April 2016

Published online: 04 June 2016

\section{References}

1. Duncan WG, Hesketh JD. Net photosynthetic rates, relative leaf growth rates and leaf numbers of 22 races of maize grown at eight temperatures. Crop Sci. 1968;8:670-4.

2. Muldoon DK, Wheeler JL, Pearson CJ. Growth mineral composition and digestibility of maize sorghum and barnyard millets at different temperatures. Aus J Agric Res. 1984;35:367-8.

3. Cutforth HW, Shaykewich CF, Cho CM. Effect of soil water and temperature on corn (Zea mays $\mathrm{L}$ ) root growth during emergence. Can J Soil Sci. 1986;66:5-8.

4. Kasper TC, Bland WI. Soil temperature and root growth. Soil Sci. 1992:154:290-9.

5. Marschner H, Römheld V, Kissel M. Localization of phytosiderophore release and of iron uptake along intact barley roots. Physiol Plant. 1987;71:157-62.

6. Shibasaki K, Uemura M, Tsurumi S, Rhman A. Auxin response in Arabidopsis under cold stress: underlying molecular mechanisms. Plant Cell. 2009;21:3823-38.

7. Tognetti VB, Mühlenbock P, van Breusegem F. Stress homeostasis-the redox and auxin perspective. Plant Cell Environ. 2012;35:321-33.

8. Stone PJ, Sorensen IB, Jamieson PD. Effect of soil temperature on phenology, canopy development, biomass and yield of maize in a cool-temperature climate. Field Crops Res. 1999:63:169-79.

9. Prasad TK, Anderson MD, Stewart CR. Acclimation, hydrogene peroxide, and abscisic acid protect mitochondria against irreversible chilling injury in maize seedlings. Plant Physiol. 1994;105:619-27.

10. Prochazkova D, Sairam RK, Srivastava GC, Singh DV. Oxidative stress and antioxidant activity as the basis of senescence in maize leaves. Plant Sci. 2001;161:765-71.

11. Kramer PJ, Boyer JS. Water relations of plants and soils. San Diego: Academic Press; 1995

12. Wan X, Zwiazek JJ, Lieffers VJ, Landhausser M. Hydraulic conductance in aspen (Populus tremuloides) seedlings exposed to low root temperatures. Tree Physiol. 2001;21:691-6.

13. Saeidnejad AH, Pouramir F, Naghizedek M. Improving chilling tolerance of maize seedlings under cold conditions by spermine application. Notulae Scientia Biologicae. 2012;4:110-7.

14. Imran M, Mahmood A, Römhled V, Neumann G. Nutrient seed priming improves seedling development of maize exposed to low root zone temperatures during early growth. Eur J Agron. 2013:49:141-8.

15. Sangha JS, Kelloway S, Critchley AT, Prithiviraj B. Seaweeds (macroalgae) and their extracts as contributors of plant productivity and quality: the current status of our understanding. Adv Bot Res. 2014;71:189-219.

16. Subramanian P. 2011 Psychrotolerance mechanisms in cold-adapted bacteria and their perspectives as plant growth-promoting bacteria in temperate agriculture. Korean J Soil Sci. Fert. 2011;44(4):625-36.

17. Cakmak I. Possible role of zinc in protecting plant cells from damage by reactive oxygen species. New Phytol. 2000;146:185-205.
18. Gericke S, Kurmis B. Die kolorimetrische Phophorsäurebestimmung mit Ammonium-Vanadat-Molybdat und ihre Anwendung in der Pflanzenanalyse. Z Pflanzenernaehr Bodenkd. 1952;59:235-47.

19. Beauchamp C, Fridovich I. Superoxide dismutase: improved assays and an assay applicable to acrylamide gels. Anal Biochem. 1971;44:276-87.

20. Giannopolitis CN, Ries SK. Superoxide dismutases-occurrence in higher plants. Plant Physiol. 1977;59:309-14.

21. Hajiboland R, Hasani BD. Responses of antioxidant defense capacity and photosynthesis of bean (Phaseolus vulgaris L.) plants to copper and manganese toxicity under different light intensities. Acta Biologica Szegediensis. 2007:51:93-106.

22. Neumann G, Römheld V. (2002): Root-induced changes in the availability of nutrients in the rhizosphere. In: Waisel Y, Eshel A, Kafkafi U, editors. Plant Roots The Hidden Half. 3rd ed. New York: Marcel Dekker; 2002. p. 617-49.

23. Reuter DJ, Robinson BJ. Plant analysis: an interpretation manual. Collingwood: CSIRO Publishing; 1997.

24. Fröhlich A, Buddrus-Schiemann K, Durner J, von Hartmann A, Rad U. Response of barley to root colonization by Pseudomonas sp. DSMZ 13134 under laboratory, greenhouse, and field conditions. J Plant Interact. 2012;7:1-9.

25. Qiao J-Q, Wu H-J, Huo R, Gao X-W, Borriss R. Stimulation and biocontrol by Bacillus amyloliquefaciens subsp. plantarum FZB42 engineered for improved action. Chem Biol Technol Agric. 2014;1:12.

26. Nkebiwe PM, Weinmann M, Weber N, Neumann G, Müller T. Placement of Pseudomonas sp. DSMZ13134 around $\mathrm{NH}_{4}{ }^{+}$-based fertilizer depots in maize stimulates root exploitation of the fertilizer depot in soil. In: Jahrestagung der DBG "Unsere Böden - Unser Leben”, München; 2015.

27. Brecht J. Wurzelbesiedlung und Wachstumsstimulierung durch Bacillus amyloliquefaciens FZB42 während Keimung und Jugendwachstum von Mais (Zea mays cv. Colissee). Bachelorarbeit; 2015; Universität Hohenheim, Germany.

28. Mittler R. Oxidative stress, antioxidants and stress tolerance. Trends Plant Sci. 2002:2002(7):405-10

29. Baek KH, Skinner DZ. Production of reactive oxygen species by freezing stress, and the protective roles of antioxidant enzymes in plants. J Agric Chem Environ. 2012;1:34-40.

30. Du H, Liu H, Xiong L. Endogenous auxin and jasmonic acid levels are differentially modulated by abiotic stress in rice. Front Plant Sci. 2013;4(397):1-10.

31. Rayirath P, Benkel BD, Mark Hodges M, Allan-Wojtas P, MacKinnon S, Critchley AT, Prithiviraj B, Lipophilic components of the brown seaweed, Ascophyllum nodosum, enhance freezing tolerance in Arabidopsis thaliana. Planta. 2009;230:135-47.

32. Engels $\mathrm{C}$, Marschner $\mathrm{H}$. Root to shoot translocation of macronutrients in relation to shoot demand in maize (Zea mays L.) grown at different root zone temperatures. J Plant Nutr Soil Sci. 1992;155:121-8.

33. Engels $\mathrm{C}$, Marschner $\mathrm{H}$. Effects of suboptimal root zone temperatures and shoot demand on net translocation of micronutrients from the roots to the shoot of maize. Plant Soil. 1996;186:311-20.

34. Datnoff $L E$, Elmer WH, Huber DG. Mineral Nutrition and Plant Disease. Minnesota: The American Phytopathological Society; 2007.

\section{Submit your manuscript to a SpringerOpen ${ }^{\circ}$ journal and benefit from:}

- Convenient online submission

- Rigorous peer review

Immediate publication on acceptance

- Open access: articles freely available online

- High visibility within the field

- Retaining the copyright to your article

Submit your next manuscript at springeropen.com 